\title{
Analysis and Assessment of Biological Treatment Processes in a Small-Scale Wastewater Treatment Plant
}

\author{
Aušra Mažeikienė, Rasa Vaiškūnaitė* \\ Department of Environmental Protection and Water Engineering, Faculty of Environmental Engineering, \\ Vilnius Gediminas Technical University, Vilnius, Lithuania
}

Received: 25 July 2017

Accepted: 24 September 2017

\begin{abstract}
With stricter requirements for wastewater treatment, small-scale individual wastewater treatment plants can provide a financially attractive alternative to a sever connection in locations far from the existing sewer network. Systems operating under the basis of active sludge are considered advanced, and their producers declare high levels of wastewater treatment not only according to BOD, but also under biogenic materials. However, there are hardly any data on how small-scale individual household wastewater treatment facilities operate. This article presents an analysis of the main parameters of wastewater biologically treated in three small-scale household wastewater treatment plants (which operate under the basis of active sludge), namely TSS, COD, $\mathrm{BOD}_{7}, \mathrm{~N}_{\mathrm{t}} \mathrm{NO}_{3}-\mathrm{N}, \mathrm{NH}_{4}-\mathrm{N}, \mathrm{P}_{t}$ and $\mathrm{PO}_{4}-\mathrm{P}$ concentrations. The research lasted for 5.5 months during a cold period. According to TSS, $\mathrm{COD}$, and $\mathrm{BOD}_{7}$ concentrations in effluent, the wastewater treatment level in the study plants was good. The concentrations of these substances in effluent $\left(\mathrm{TSS}<10 \mathrm{mg} / \mathrm{L}, \mathrm{COD}<98 \mathrm{mg} / \mathrm{L}, \mathrm{BOD}_{7}<20 \mathrm{mg} / \mathrm{L}\right.$ ) were lower than requirements for treated water. However, $\mathrm{NH}_{4}-\mathrm{N}$ in the effluent in winter increased up to $6-7 \mathrm{mg} / \mathrm{L}$ and to $26 \mathrm{mg} / \mathrm{L}$. The concentrations of $\mathrm{N}_{\mathrm{t}}$ and $\mathrm{P}_{\mathrm{t}}$ in treated wastewater exceeded $\mathrm{EU}$ requirements for water released from wastewater treatment facilities. $\mathrm{PO}_{4}$-P removal, in many cases, was ineffective or did not take place at all.
\end{abstract}

Keywords: wastewater, treatment plant, small, individual, activated sludge

\section{Introduction}

In recent years the variety of different types of smallscale household wastewater treatment plants produced in Lithuania and abroad has increased considerably within the country. However, there are hardly any data on how such small-scale plants operate. Decentralized or in-situ

*e-mail: rasa.vaiskunaite@vgtu.lt wastewater treatment systems for a long time have been considered a major source of $\mathrm{N}$ inputs to surface- and groundwater [1]. The exploitation data for small-scale wastewater treatment plants in use in Lithuania have not been properly analyzed nor given a critical assessment. Literature sources most frequently provide merely a statistical evaluation of such plants [2-4]. The factors that could disturb the biological treatment process, e.g. possible fluctuations in wastewater concentration and flow and a rather cold climate, are mostly underestimated [5-10]. The quality standards of wastewater discharged in small-scale 
plants is worse than in large ones, where municipal sewage systems smooth out both yield and pollution fluctuations, whereas other authors state that the results achieved in small-scale plants ensure the reliability and financial advantage of small-scale wastewater treatment plants against the currently existing centralized systems $[2,4,11$ 13]. This article presents an analysis of exploitation of the most popular small-scale plants in Lithuania intended for intensive biological treatment of household wastewater. It should be noted (as manufacturers state) that one circular tank in this plant is designed for removal of nitrogen and phosphorus compounds from wastewater. The removal of biogenic substances from wastewater is very important in terms of environmental protection and can be achieved only with the help of innovative technologies [14-18].

In Lithuania, statutory requirements for nitrogen and phosphorus compound amounts released into the environment are established only for wastewater treatment plants that release into the environment $\geq 5 \mathrm{~m}^{3} / \mathrm{d}$ of wastewater, taking into consideration the allowable impact on surface waters, [19] whereas in small-scale plants with less than $5 \mathrm{~m}^{3} / \mathrm{d}$ of discharged wastewater only $\mathrm{BOD}_{7}(\mathrm{mg} / \mathrm{L})$ is controlled. Nevertheless, environmental requirements are becoming stricter and concentrations of other substances, such as nitrogen and phosphorus compounds, should also be observed. The territory of Lithuania is attributed to a eutrophication-sensitive area where more stringent requirements have to be applied for the discharge of wastewater. Manufacturers state that wastewater treated with small plants may be released into open water bodies, infiltrated into the ground, released into rainwater collection systems, or used as technical water.

For such plants to become acceptable among individual users and businesses, a comprehensive analysis of operation of small activated sludge plants is necessary. Whenever wastewater is released into the natural environment, wastewater amounts and residual concentrations of pollutants should be evaluated, and exploitation of wastewater treatment plants should be analyzed in detail.

\section{Methodology}

\section{Object}

The researched wastewater treatment plants (AUGUST AT and BIOCLAR B models) are one-block facilities. The entire wastewater treatment process takes place in a vertical-flow labyrinth, and the condition of oxygen in certain zones is regulated only by an air blower and airlifts. A scheme of the plants is given in Fig. 1.

The studied household wastewater treatment plants (Fig. 1) are composed of an anaerobic tank of 4 sections, the first of which has a collecting bag for wastewater collection (2), an aeration tank (5), and a secondary settling tank (7) with a flow regulator (11) to protect the system from overflow. The anaerobic tank is partitioned into down-flow and up-flow sections $(3,4)$. By airlifts installed under the collecting bag, the sludge mixture is pumped from one section to the other, thus ensuring internal circulation in the anaerobic tank. Three pieces of equipment of the same type - AT-6 (No.1), B-6 (No.2), and AT-8 (No.3) - were selected for research (Table 1).

The selected devices are popular and are considered to be the best in Lithuania. They are manufactured, sold, and installed by AUGUST \& KO. The plants operate mechanically and biologically, and no reagents are used for wastewater treatment.

The management and maintenance of these facilities is carried out by suppliers. Consumers are obliged to visually inspect the equipment once a month [2-4].

The plants are located near living houses in a gardening community in the city of Vilnius $(1,2)$ or Vilnius district (3). Efficiencies of the plants are 0.54-1.2 $\mathrm{m}^{3} / \mathrm{d}$, and reservoir volumes are 1.7-2.5 $\mathrm{m}^{3}$ (Table 1). Hydraulic retention time (HRT) in all plants was about 3 days. The sludge retention time (SRT) in this system was about 3-4 months. The sludge was removed twice per year. Treated wastewater (from devices 1 and 2) was released into an infiltration well. The prevailing soil in the land plot was sandy loam and sand. Treated wastewater from device 3 was released into the Vilnia River.

\section{Experiment Course}

The study period lasted from 03.11.2015 to 12.04.2016. The following parameters of treated wastewater were measured: temperature, total suspended solids (TSS), $\mathrm{pH}, \mathrm{COD}, \mathrm{BOD}_{7}$, nitrate nitrogen $\left(\mathrm{NO}_{3}-\mathrm{N}\right)$, ammonium nitrogen $\left(\mathrm{NH}_{4}-\mathrm{N}\right)$, total nitrogen $\left(\mathrm{N}_{\mathrm{t}}\right)$, total phosphorus $\left(\mathrm{P}_{\mathrm{t}}\right)$, and orthophosphate phosphorus $\left(\mathrm{PO}_{4}-\mathrm{P}\right)$ concentrations. Enzyme activity of activated sludge and compositions of microorganisms were determined.

The samples of treated wastewater $(0.5 \mathrm{~L})$ were taken from the secondary settling tank once a week (usually on Tuesdays) at approximately 08:00, and their temperature and $\mathrm{pH}$ were measured. Other parameters were measured in a laboratory of the Water Management Department of Vilnius Gediminas Technical University (VGTU). The samples were filtered through paper filters, and $\mathrm{BOD}_{7}, \mathrm{NO}_{3}-\mathrm{N}, \mathrm{NH}_{4}-\mathrm{N}$, and $\mathrm{PO}_{4}-\mathrm{P}$ concentrations were immediately measured. Each parameter was measured three times, and average values were recorded. $\mathrm{BOD}_{7}$ was measured according to the analysis method specified in Lithuanian environmental document LAND 21-01. The concentration of TSS in samples of treated wastewater was measured in the laboratory: samples were filtered through glass fiber filters and the sludge was dried to a constant weight at $105^{\circ} \mathrm{C}$ (LST EN 872:2005; water quality; determination of suspended solids; method by filtration through glass fiber filter). The value of $\mathrm{pH}$ has been fixed potentiometric (LST EN ISO 10523:2012) as measured by a microprocessor $\mathrm{pH}-211$ (Hanna Instruments Inc.). Certified reference buffers of Hamilton (Switzerland) $\mathrm{pH}$ $7.00 \pm 0.01$ and $\mathrm{pH} 9.21 \pm 0.02$ were used for the control of measurement quality. Chemical oxygen consumption was the fixed titrimetric method. The index of bichromatic 


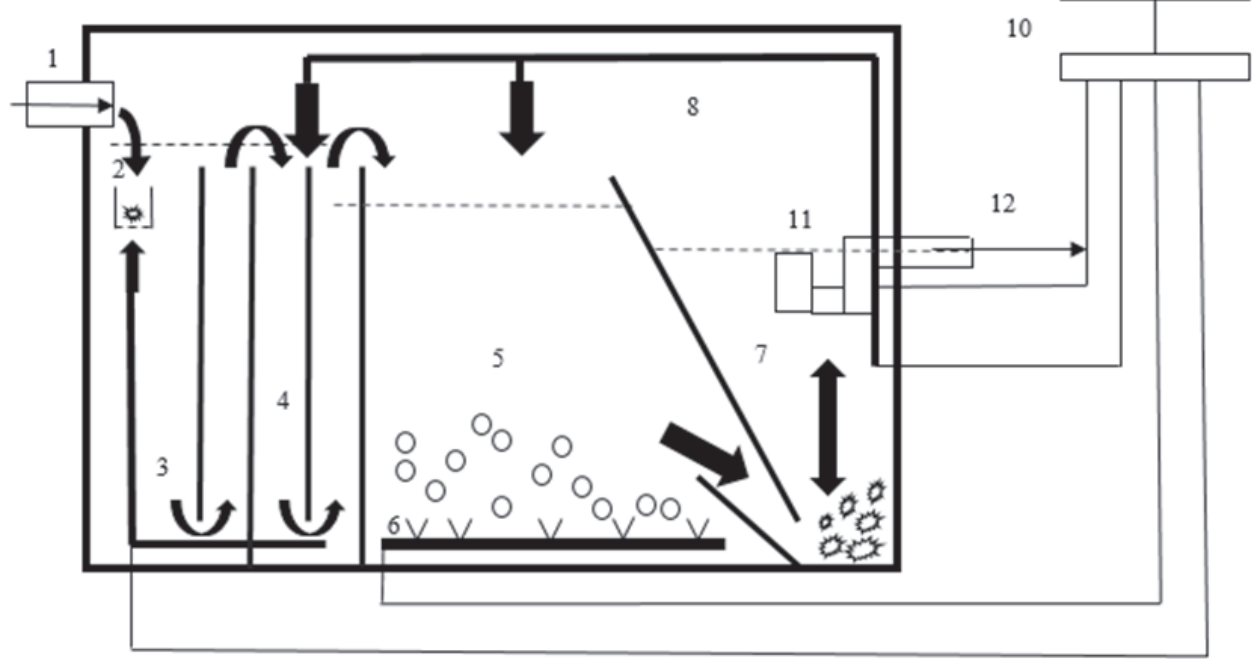

Fig. 1. Wastewater treatment plant scheme: 1 - inflow, 2 - bag for wastewater collection (grating), 3 - airlift 1, 4-anaerobic chamber, 5 - aerobic chamber, 6 - tubular diffuser, 7 - zone of settling tank, 8 - airlift 2, 9 - air blower, 10 - air distribution system, 11 - flow regulator, 12 - outflow.

oxidation was conducted by thermoreactor Eco-6 of Velp Scientifica (Italy). Excess oxidizer was titrated according to the methodology approved by LAND 83-2006 [19].

The temperature of the sewage mixture and dissolved oxygen $\left(\mathrm{O}_{2}\right)$ have been measured locally, in the aeration and anaerobic sections by an OXI 330/SET oximeter.

Concentrations of other parameters were measured by appropriate tests and a MERC Spectroquant NOVA 60 spectrometer. Each activated sludge sample (1L) taken from the aerobic tank was put into a $3 \mathrm{~L}$ glass jar and transported for examination to the laboratory of the VGTU Water Management Department. The samples were brought to the laboratory within $30 \mathrm{~min}$ and were immediately examined under a microscope MOTIC B1 with achromatic objectives. If there was no possibility to examine activated sludge immediately, it was aerated in a glass vessel for about 24 hours.

\section{Results and Discussion}

During the study period, average ambient temperature for the period of 5.5 months was $\sim 3^{\circ} \mathrm{C}$, It ranged from -23 (January) to $+20^{\circ} \mathrm{C}$ (April), but the temperature of treated wastewater and activated sludge samples varied less, changing from 7.5 to $12.0^{\circ} \mathrm{C}$. The temperature of wastewater was not reduced because it did not undergo primary treatment before getting into the plant. There are no septic tanks. The distance from the living houses to the plants was merely 5-15 m, thus wastewater temperature hardly changed. In the aeration tanks, an exothermal process, i.e., biochemical oxidation of substances under aeration conditions, took place. During the exothermal process, organic substances were degraded up to inorganic compounds.

At the same time, a new biomass was synthesized. The general form for the main elements of the new biomass could be expressed by the formula $\mathrm{C}_{5} \mathrm{H}_{7} \mathrm{NO}_{2}$. The reaction of biomass synthesis was also exothermal. The $\mathrm{BOD}_{7}$ concentration of treated wastewater was found to have never exceeded $20 \mathrm{mg} / \mathrm{L}$ during the 5.5-month study period of all three pieces of equipment (Table 2). This is a good result, because the Regulation on Wastewater Management of Lithuania establishes that the average annual $\mathrm{BOD}_{7}$ concentration in treated wastewater should not exceed $35 \mathrm{mg} / \mathrm{L}$, and the highest momentary concentration should not be higher than $58 \mathrm{mg} / \mathrm{L}$ in smallscale wastewater treatment plants (with the treatment capacity of up to $5 \mathrm{~m}^{3} /$ day). $\mathrm{BOD}_{7}$ is the only parameter for small-scale wastewater treatment plants (up to $5 \mathrm{~m}^{3} /$ day) controlled by the Regulation on Wastewater Management [19]. Yet this requirement for $\mathrm{BOD}_{7}$ is applied only

Table 1 . The researched devices

\begin{tabular}{|c|c|c|c|c|c|}
\hline No. & Number of people & Flow rate $\left(\mathrm{m}^{3} / \mathrm{d}\right)$ & Volume $\left(\mathrm{m}^{3}\right)$ & Operation period (years) & Wastewater receiver \\
\hline 1 & 4 & 0.54 & 1.7 & 3 & Infiltrating soil \\
\hline 2 & 3 & 0.9 & 2.5 & 2 & Infiltrating soil \\
\hline 3 & 4 & 0.81 & 2.3 & 3 & Into Vilnia River \\
\hline
\end{tabular}


Table 2. Comparison of treated wastewater quality treatment rates $(\mathrm{mg} / \mathrm{L})$.

\begin{tabular}{|c|c|c|c|c|c|c|c|c|c|c|}
\hline \multicolumn{11}{|c|}{ Parameters } \\
\hline Value & TSS & $\mathrm{pH}$ & COD & $\mathrm{BOD}_{7}$ & $\mathrm{NH}_{4}-\mathrm{N}$ & $\mathrm{NO}_{3}-\mathrm{N}$ & $\mathrm{NO}_{2}-\mathrm{N}$ & $\mathrm{PO}_{4}-\mathrm{P}$ & $N_{t}$ & $P_{t}$ \\
\hline \multicolumn{11}{|c|}{ Device 1} \\
\hline Min. & $2 \pm 1$ & $7.4 \pm 0.2$ & $36.2 \pm 5.5$ & $4.8 \pm 0.3$ & $6.05 \pm 0.15$ & $0.05 \pm 0.01$ & $0.07 \pm 0.02$ & $4.31 \pm 0.4$ & $7.25 \pm 0.5$ & $5.95 \pm 0.5$ \\
\hline Max. & $9 \pm 2$ & $8.5 \pm 0.1$ & $97.7 \pm 7.2$ & $20.0 \pm 2.4$ & $51.49 \pm 4.5$ & $3.87 \pm 0.3$ & $0.11 \pm 0.03$ & $16.5 \pm 1.5$ & $55.75 \pm 4.5$ & $18.03 \pm 1.5$ \\
\hline Aver. & $5 \pm 1$ & $7.7 \pm 0.2$ & $67.4 \pm 5.7$ & $11.0 \pm 1.9$ & $26.01 \pm 3.4$ & $1.32 \pm 0.2$ & $0.09 \pm 0.02$ & $9.9 \pm 1.0$ & $35.04 \pm 3.3$ & $11.25 \pm 1.0$ \\
\hline \multicolumn{11}{|c|}{ Device 2} \\
\hline Min. & $1 \pm 1$ & $7.2 \pm 0.1$ & $17.4 \pm 6.3$ & $2.9 \pm 0.5$ & $0.5 \pm 0.05$ & $4.42 \pm 0,3$ & $0.05 \pm 0.01$ & $0.6 \pm 0.05$ & $5.45 \pm 0.3$ & $1.1 \pm 0.1$ \\
\hline Max. & $5 \pm 1$ & $8.0 \pm 0.1$ & $51.8 \pm 4.8$ & $7.3 \pm 0.7$ & $6.30 \pm 0.5$ & $8.63 \pm 0.6$ & $0.1 \pm 0.05$ & $6.92 \pm 0.5$ & $16.3 \pm 1.1$ & $8.9 \pm 0.7$ \\
\hline Aver. & $3 \pm 1$ & $7.8 \pm 0.2$ & $28.1 \pm 2.7$ & $4.5 \pm 0.6$ & $3.49 \pm 0.09$ & $6.09 \pm 0.4$ & $0.08 \pm 0.02$ & $4.63 \pm 0.3$ & $12.0 \pm 0.9$ & $6.3 \pm 0.5$ \\
\hline \multicolumn{11}{|c|}{ Device 3} \\
\hline Min. & $3 \pm 1$ & $7.4 \pm 0.1$ & $20.5 \pm 2.4$ & $3.9 \pm 0.6$ & $2.2 \pm 0.05$ & $4.9 \pm 0.4$ & $0.04 \pm 0.01$ & $0.9 \pm 0.1$ & $8.34 \pm 0.7$ & $1.8 \pm 0.2$ \\
\hline Max. & $6 \pm 2$ & $7.8 \pm 0.2$ & $65.1 \pm 5.8$ & $9.5 \pm 1.0$ & $8.52 \pm 0.6$ & $9.45 \pm 0.8$ & $0.09 \pm 0.02$ & $8.5 \pm 0.6$ & $19.45 \pm 1.5$ & $10.1 \pm 0.9$ \\
\hline Aver. & $4 \pm 1$ & $7.6 \pm 0.2$ & $48.5 \pm 3.9$ & $6.1 \pm 0.7$ & $5.87 \pm 0.4$ & $7.32 \pm 0.6$ & $0.07 \pm 0.02$ & $4.97 \pm 0.3$ & $15.2 \pm 1.2$ & $5.3 \pm 0.4$ \\
\hline \multicolumn{11}{|c|}{ Highest allowable concentration (HAC) for release into natural environment in Lithuania } \\
\hline- & - & - & - & 35 & 5 & 23 & - & - & 30 & 4 \\
\hline \multicolumn{11}{|c|}{ Results of Vilnius city wastewater treatment plant } \\
\hline- & 22 & - & 43 & 11.5 & - & - & - & - & 8.6 & 0.8 \\
\hline \multicolumn{11}{|c|}{ EU requirements for water released from wastewater treatment facilities } \\
\hline- & 25 & - & 125 & 15 & - & - & - & - & 10 & 1 \\
\hline
\end{tabular}

when treated wastewater is released into surface water bodies. The release of treated wastewater into the ground is regulated by a Lithuanian environmental document LAND 21-01 [20]. In our case, the $\mathrm{BOD}_{7}$ concentration in treated wastewater $\left(\mathrm{BOD}_{7}<50 \mathrm{mg} / \mathrm{L}\right)$ did not exceed the allowable contamination rate and was on average 3 times lower than the rate established for infiltration of wastewater into the ground in municipal areas. Thus, according to the residual concentration of $\mathrm{BOD}_{7}$, the wastewater treated with the studied plants was fit for infiltration into the ground. Law concentrations of TSS (1-10 mg/L) and low COD (18-98 mg/L) concentrations used to remain in the treated effluents of all researched equipment.

Comparing achieved results with the results of another single-household wastewater treatment facility, the advantage can be noticed. Under treatment of wastewater by the anaerobic method in septic tanks, the following residual concentrations of pollutants are achieved: TSS - 87-123 mg/L, COD - 380-412 mg/L, and $\mathrm{BOD}_{5}-156-180 \mathrm{mg} / \mathrm{L}$ [21]. Previous research on pilotscale in a up-flow septic tank reported that the searched system generated promising results and it effectively achieved the reuse and discharge requirements for $\mathrm{BOD}_{5}$ and COD at the short HRT of $24 \mathrm{~h}$ [22]. The achieved treated wastewater concentrations are as follows: TSS - $55 \mathrm{mg} / \mathrm{L}$ (86\% efficiency), COD - $58 \mathrm{mg} / \mathrm{L}$ (77\% efficiency), and $\mathrm{BOD}_{5}-26 \mathrm{mg} / \mathrm{L}$ (85\% efficiency). Fewer pollutants expressed by TSS and $\mathrm{BOD}_{7}$ indicators remained in wastewater treated in devices AT-6, B-6, and AT-8.

Taking into account the contamination of untreated sewage (Table 3), it is seen that the treatment efficiency of TSS, COD, and BOD concentrations of all 3 devices is $>90 \%$. Meanwhile, septic tank concentrations of these pollutants are reduced by only 53-68\% [21].

The Regulation on Wastewater Management Standardizing regulating [19] the level of contamination of household wastewater into the environment does not establish allowable residual nitrogen and phosphorus compound rates for small-scale wastewater treatment plants. Therefore, the results of our measurements were compared with the rates established in other documents (Figs 2-4). The Regulation [19] assigns nitrogen and phosphorus compounds to controlled substances and establishes their allowable concentrations in wastewater. We compared our results with allowable rates set in the EU (European Directive 1991/271/EEC) and Lithuanian regulations [19], and the results obtained in the Vilnius wastewater treatment plant (Table 2). The results of device No. 1 (received in laboratory), provided by manufacturers, are shown in Table 3 [2-4]. These indicators are the results of laboratory research using Aachene (Germany) equipment. 


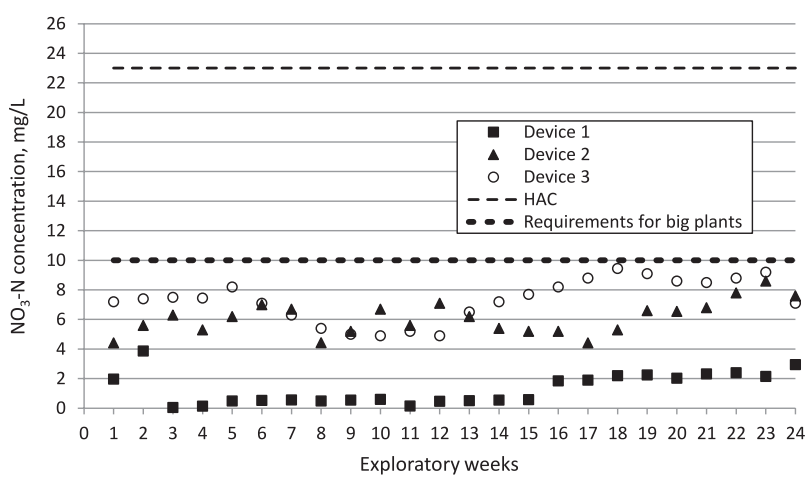

Fig. 2. Comparison of nitrate nitrogen concentrations $(\mathrm{mg} / \mathrm{L})$ during the study period.

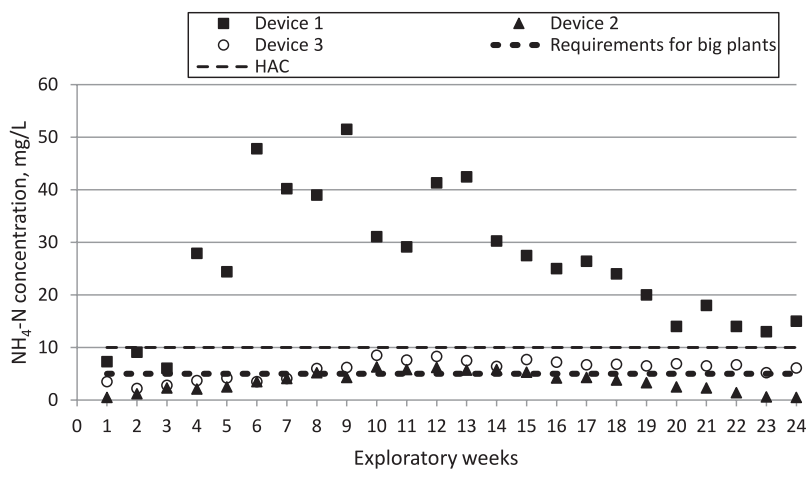

Fig. 3. Comparison of ammonium nitrogen concentrations $(\mathrm{mg} / \mathrm{L})$ during the study period.

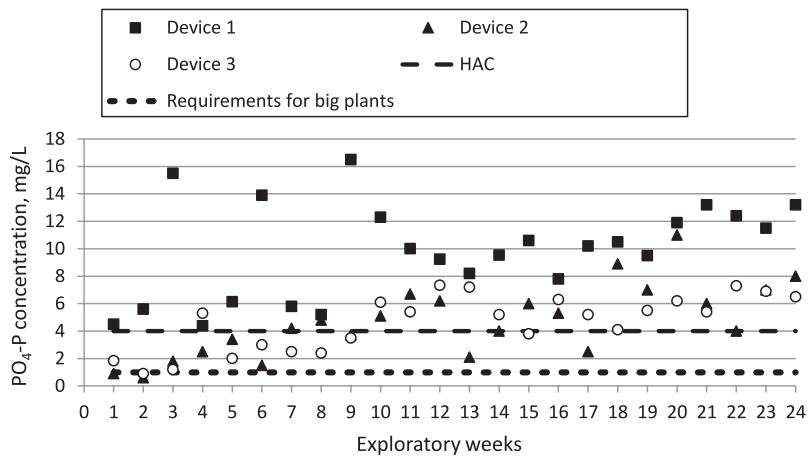

Fig. 4. Comparison of orthophosphate phosphorus concentrations $(\mathrm{mg} / \mathrm{L})$ during the study period.
Table 2 shows that nitrate nitrogen concentration in wastewater treated in the studied plants ranged from 1 to $10 \mathrm{mg} / \mathrm{L}$. It was lower than the highest allowable concentration (HAC) in wastewater released into the natural environment in Lithuania $(23 \mathrm{mg} / \mathrm{L})$. When nitrates get into the groundwater, they can pollute it and pose a threat to human health $[1,4]$.

There were several shaft wells in our study area, and their water is used for drinking. From the results obtained we can see that the quality of the denitrification process in the plant was good. The dissolved oxygen concentration reached $0.1-0.4 \mathrm{mg} / \mathrm{L}$ and met the requirement of $<0.5 \mathrm{mg} / \mathrm{L}$ during the experiment of researched facilities in anaerobic $[16,18]$. Residual $\mathrm{NO}_{3}-\mathrm{N}$ in all three devices was lower than the HAC. In addition, it did not exceed the achieved results of a large wastewater treatment plant according to total nitrogen (Table 2). The limit value of total nitrogen established for the large-scale wastewater treatment plant in Vilnius $\left(225,000 \mathrm{~m}^{3} / \mathrm{d}\right.$ efficiency), which treated wastewater destined for the river, is $10 \mathrm{mg} / \mathrm{L} \mathrm{[19].} \mathrm{Compared} \mathrm{with}$ biological nutrient removal in a small-scale MBR treating household wastewater [6], nitrate nitrogen in our case remains 4.5 times less in wastewater treated in a membrane bioreactor (their $-45 \mathrm{mg} / \mathrm{L}$ ).

Fig. 3 shows average concentrations of ammonium ions in the wastewater from device 1. On the fourth week of research (December 2015) we observed that the amount of dissolved oxygen in the aeration zone (No. 1) of the device is only $0.5-1.1 \mathrm{mg} / \mathrm{L}$. By increasing the content supply of oxygen to $2.0 \mathrm{mg} / \mathrm{L}$, further oxidation of ammonium in device No. 1 was still worse than in the other two devices. This can be explained by the long period of development by properties of nitrifying bacteria, which are sensitive to changes in environmental conditions. Larger concentrations of $\mathrm{NH}_{4}-\mathrm{N}$ were detected in weeks 6 and 9 (January) when the outside temperature was the lowest $\left(-23\right.$ and $\left.-17^{\circ} \mathrm{C}\right)$. Ammonium ion concentration increases in winter are noticeable in treated wastewater for another two devices (Nos. 2 and 3). According to scientific literature, in order to ensure continuous nitrification, temperature should not change or should change only insignificantly, sludge age should not be less than 724 hour periods, and wastewater should contain a sufficient amount of dissolved oxygen ( $\geq 2 \mathrm{mg} / \mathrm{L})[12,18]$. The operation of the air blower was controlled by a stopwatch to ensure its periodical operation. During the research period, dissolved oxygen concentrations in devices 2 and 3 were above 2-4 mg/L. Sludge age (of all three facilities)

Table 3. Domestic sewage contamination and clean-up indicators [2, 4].

\begin{tabular}{|c|c|c|c|c|c|c|}
\hline Indicator & $\begin{array}{c}\mathrm{TSS} \\
(\mathrm{mg} / \mathrm{L})\end{array}$ & $\begin{array}{c}\mathrm{COD} \\
(\mathrm{mg} / \mathrm{L})\end{array}$ & $\begin{array}{c}\mathrm{BOD}_{7} \\
(\mathrm{mg} / \mathrm{L})\end{array}$ & $\begin{array}{c}\mathrm{N}_{\mathrm{t}} \\
\mathrm{mg} / \mathrm{L})\end{array}$ & $\begin{array}{c}\mathrm{NH}_{4}-\mathrm{N} \\
(\mathrm{mg} / \mathrm{L})\end{array}$ & $\begin{array}{c}\mathrm{P}_{\mathrm{t}} \\
(\mathrm{mg} / \mathrm{L})\end{array}$ \\
\hline Untreated wastewater & 431 & 800 & 372 & 82.4 & 40 & 9 \\
\hline Treated wastewater & 25.9 & 95.2 & 10.4 & 31.6 & 1.3 & 4.37 \\
\hline Efficiency of treatment (\%) & 94.0 & 88.1 & 97.2 & 61.7 & 96.7 & 47.4 \\
\hline
\end{tabular}


was above 30 24-hour periods, and temperature changed from 7.5 to $12.0^{\circ} \mathrm{C}$. As claimed in scientific literature, nitrifying bacteria are known to be very sensitive to low temperatures, and nitrification can be strongly inhibited by low temperatures [24-27]. It is stated that when low temperature (below $8^{\circ} \mathrm{C}$ and lower nitrification rate) was observed [27], it might indicated that January frosts negatively affected the nitrification process.

The effects of individual factors, however, have not been evaluated. Some nitrifying bacteria (for example $N$. oligotropha) strains vary in their adaptation to chemical and physical conditions [28]. For example, in conventional septic tank effluent ammonium nitrogen used to remain at $26.6 \mathrm{mg} / \mathrm{L}$ when HRT was $24 \mathrm{~h}$ [25]. However, we found higher concentrations of ammonium nitrogen than those declared by manufacturers under real operation of devices in winter conditions (Table 3).

Table 2 and Fig. 4 present phosphate phosphorus concentrations, which accounted for the major part (ca. $80 \%$ ) of $\mathrm{P}_{\mathrm{t}}$ in the studied plant. The concentrations recorded in the studied plant exceeded allowable concentrations. High concentrations of phosphates in treated wastewater can be attributed to a long sludge age. It is common knowledge that biological removal of phosphate from wastewater is based on the ability of bacteria, which intensively uses phosphates to accumulate a great amount of phosphorus in anaerobic-aerobic conditions. In wastewater treatment plants, phosphorus is removed from the system together with excess activated sludge, where sludge age, i.e., duration of activated sludge renewal in the system, is very important. At the time that phosphorus is being removed from wastewater, sludge age should be possibly shorter for a greater amount of sludge (including phosphorus) to be removed. When wastewater treatment is performed at full oxidation regime and nitrification proceeds at full capacity (our case), the biological use of phosphorus is the smallest because of the smallest growth of activated sludge. This is the main objection arising in the systems when nitrogen and phosphorus are biologically removed at the same time. In the studied plant, sludge age was $>30$ 24-hour periods, which means that sludge was aerobically stabilized. It was disposed of 1-2 times per year. In December 2015, high biomass concentration caused a disruption in oxygen supply to the bioreactor of one device because a diffuser in the aeration tank (Figs 1-2) got clogged. The disruption was noticed after 1-7 days; therefore, it affected the composition of microorganisms in the activated sludge and the removal of nitrogen and phosphorus. Measured sludge volume index (SVI), which was previously $\leq 100 \mathrm{~mL} / \mathrm{g}$, now exceeded $160 \mathrm{~mL} / \mathrm{g}$ [29], which was caused by lack of oxygen starting activated sludge bulking.

As the duration of anaerobic contact increased, accumulation of polyphosphates in microorganisms accumulating polyphosphates was disrupted, because in the anaerobic zone the consumption of easily biodegradable pollutants by such microorganisms was worse. As we can see from Fig. 4, orthophosphate phosphorus concentrations increased (and in device Nos. 2 and 3).
The concentration of phosphate phosphorus $\left(\mathrm{PO}_{4}-\mathrm{P}\right)$ in tested samples exceeded the HAC of total phosphorus according to List B2 of Annex 2 of the Regulation on Wastewater Management of Lithuania. Cleaning wastewater in a UASB septic tank, nutrients, as expected, were not removed in reactors and only a change in the chemical forms of $\mathrm{N}$ and $\mathrm{P}$ took place [30]. While cleaning wastewater in a household membrane bioreactor plant [9], it became clear that the membrane unit was the only device to guarantee the superior long-term quality of the effluent. Good phosphorus removal was seen in the minor devices in Stockholm. The balance of $\mathrm{P}_{\mathrm{t}}$ in cleaned wastewater was $0.72 \mathrm{mg} / \mathrm{L}, \mathrm{PO}_{4}-\mathrm{P}-0.2 \mathrm{mg} / \mathrm{L}$. However, plants utilize chemicals to precipitate phosphorus. Compared with the indicators presented by manufacturers (Table 3 ), the content of phosphorus compounds in treated wastewater remains higher than declared.

Fig. 5 presents photos (400 x magnification) of microorganisms of activated sludge taken in November 2015. Sessile ciliates $[25,29]$ were found in all devices. In the samples of activated sludge examined before December 2015, the microorganisms typical of the stabilized long-age sludge were recorded. Such microorganisms contribute to the biodegradation of organic matter. The absence or very low density of protozoa (ciliates) in activated sludge
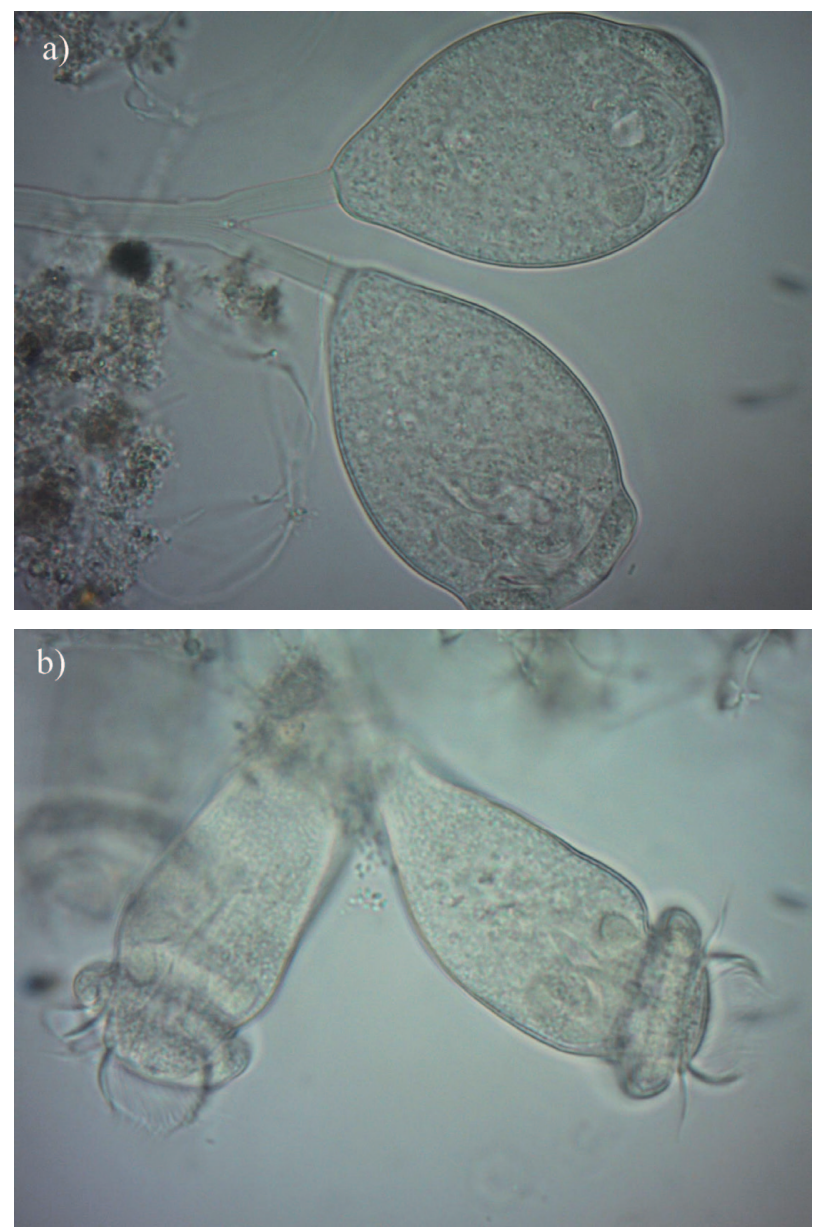

Fig. 5. Sessile ciliates as indicators of activated sludge: a) Vorticella, b) Epistylis 


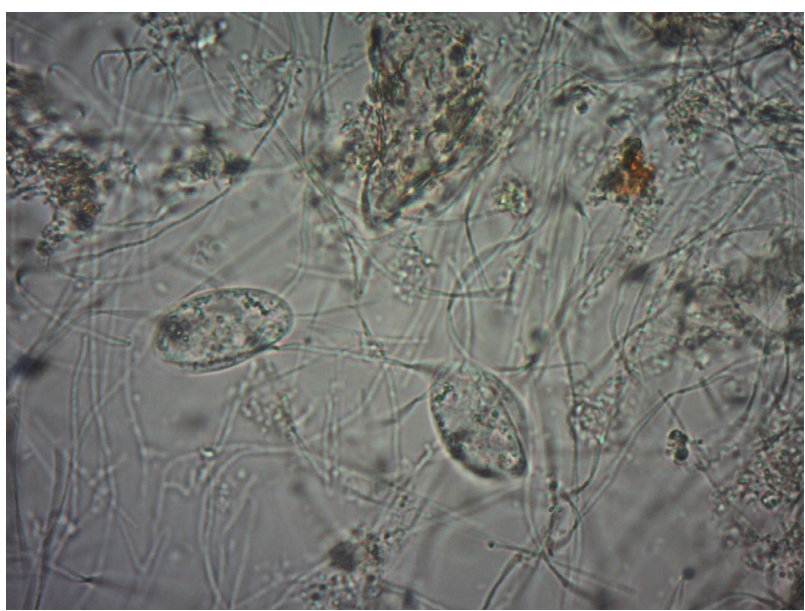

Fig. 6. Threadlike microorganisms in activated sludge of one plant.

was found to be often related to relatively poor-quality wastewater treatment [29]. Sessile ciliates are indicators of good sludge circulation: if a wastewater treatment plant is operating properly and sludge circulation is good, then the number of mobile ciliates is approximately equal to the number of sessile ciliates. Abundantly growing sessile ciliates are characteristic of high-quality activated sludge (Fig. 5).

Rotifers were found as well. They are indicators of low loading of activated sludge with wastewater pollutants, the long age of sludge, and effective nitrification process. A microbiological analysis of activated sludge confirmed the results presented in Table 2, which show that in rather low concentrations of organic substances (according to $\mathrm{BOD}_{7}$ ) and TSS, COD remained in treated wastewater.

When oxygen supply to the aeration tank (first device) was disrupted in December 2015, activated sludge was found to contain a greater amount of threadlike microorganisms (Fig. 6), which are usually undesirable.

The latter phenomenon could be explained by the plasticity of microorganisms and their ability to promptly adapt to environmental changes. In 2016 sludge samples were no longer found to contain indicators characteristic of efficiently functioning activated sludge, i.e., sessile ciliates, rotifers, testate amoebae, etc. However, the situation has worsened, and the construction of the plant allowed treated wastewater to remain in the settling tank rather too long for clarifying. Therefore, taking samples at the same time of the day according to the established method ensured rather good results. However, the possibility of discharge of pollutants (according to the BOD) from the plant cannot be overlooked in the case of great momentary wastewater in flows. Wastewater pollutants were degraded even when the diffuser was clogged (in operating airlifters); changes in the composition of microorganisms reduced wastewater pollution according to the BOD upon the occurrence of sufficient enzyme activity.

Compared with other small devices $[1,7]$, the received results are good. For example, many installed individual systems in Belgium [7] do not perform well: $52 \%$ of them do not meet all the legal effluent standards $\left(\mathrm{BOD}_{7}\right.$, COD, TSS). American researchers have made similar claims: the vast majority of OWTs do not approach the reliability and stability of centralized treatment and cannot comply with most effluent standards with $50 \%$ probability [1]. According to the authors, in most developing countries small devices might be the most appropriate, environmentally friendly, and least costly treatment options, and they allow maximum flexibility in planning for future development [6, 32-35].

During winter operation of such facilities, actual results differ from those declared by the manufacturer according to residual $\mathrm{N}$ and $\mathrm{P}$ concentrations of compounds. The least-tested facility (No. 1) was the least efficient at wastewater treatment, which resulted in the highest concentrations of $\mathrm{COD}, \mathrm{BOD}_{7}$, and $\mathrm{N}_{\mathrm{t}}$. Facilities with a flow rate of less than $0.8 \mathrm{~m}^{3} / \mathrm{d}$ are sensitive and do not ensure sufficient disposal of biogenic materials from wastewater. It is noted that small individual facilities require complex control of nitrogen and phosphorus compound removal and regular maintenance. The success of decentralized wastewater treatment depends on how well the maintenance and inspection of individual treatment plants is implemented. Typically, the maintenance of these facilities is the responsibility of their owner, but due to various reasons (time lag, savings, etc.) the owner may not be able to provide proper maintenance [35].

Often, owners of wastewater treatment plants do not know how their systems operate and what the consequences of bad equipment work are. Therefore, it is necessary to educate the owners on wastewater treatment issues.

With the environmental requirements being tightened, the design of these facilities, technological processes, or maintenance have to be improved.

\section{Conclusions}

In the studied small-scale activated sludge wastewater treatment plants (all three), concentrations of $\mathrm{BOD}_{7}$ in treated wastewater never exceeded $20 \mathrm{mg} / \mathrm{L}$ throughout the study's 5.5-month period. Thus, the quality of wastewater treated in the studied plant (up to $5 \mathrm{~m}^{3} /$ day) complied with Lithuanian environmental requirements. Concentrations of TSS and COD in cleaned wastewater were lower than those achieved by many other small-decentralized devices with similar characteristics. According to biological indicators, the activated sludge in the studied plants was of good quality.

Although low nitrate concentrations were in wastewater cleaned by devices, ammonium nitrogen increased to an average of $6-7 \mathrm{mg} / \mathrm{L}$ (in devices with $0.81-0.9 \mathrm{~m}^{3} / \mathrm{d}$ flow rate), and up to $26 \mathrm{mg} / \mathrm{L}$ (in device with $0.54 \mathrm{~m}^{3} / \mathrm{d}$ flow rate). $\mathrm{N}_{\mathrm{t}}$ of three devices exceeded EU requirements for water released from wastewater treatment facilities. Under $\mathrm{P}_{\mathrm{t}}$, these EU requirements have also been exceeded in 
all three devices. With the environmental requirements being tightened, the design, technological process, and maintenance of these devices must be improved.

\section{Abbreviations}

TSS - total suspended solids,

COD - chemical oxygen demand,

$\mathrm{BOD}_{7}-$ biological oxygen demand (over 7 days),

$\mathrm{N}_{\mathrm{t}}$ - total nitrogen,

$\mathrm{NO}_{3}-\mathrm{N}-$ nitrate nitrogen,

$\mathrm{NH}_{4}-\mathrm{N}$ - ammonium nitrogen,

$\mathrm{P}_{\mathrm{t}}$ - total phosphorus,

$\mathrm{PO}_{4}-\mathrm{P}$ - orthophosphate phosphorus,

OWT - onsite wastewater treatment

\section{References}

1. OAKLEY S.M., GOLD A.J., OCZKOWSKI A.J. Nitrogen control through decentralized wastewater treatment: Process performance and alternative management strategies. Ecol Eng. 36, 1520, 2010.

2. AUGUST \& KO. 2013. Available online: $<$ http://www. august.1t/lt/produktai/biologiniai-nuoteku-valymoirenginiai/mazi-nvi-at6-at50>. Sited 10 January 2015.

3. SMALL WASTE WATER TREATMENT PLANT AT. 2013. Available online: https://www.youtube.com/ watch? $v=u$ VczI-QgNkw. Sited 10 January 2017.

4. BUDRECKAS A. Leaving behind the time of lithuanian "August ir Ko" biological wastewater treatment plant technology [in Lithuanian language]. Water Management. Information publication of Lithuanian Water Association (in lithuanian language: Vandentvarka. Lietuvos vandens asociacijos informacinis leidinys). 45, 16, 2014.

5. ENGIN G.O., DEMIR I. Cost analysis of alternative methods for wastewater handling in small communities. J Environ Manage. 79, 357, 2006.

6. ABEGGLEN C., OSPELT M., SIEGRIST H. Biological nutrient removal in a small-scale MBR treating household wastewater. Water Res. 42, 338, 2008

7. MOELANTS N., ET AL. Field performance assessment of onsite individual wastewater treatment systems. Water Sci Technol. 58 (1), 1, 2008.

8. LOWE K.S., ET AL. Field evaluation of the performance of engineered on-site wastewater treatment units. J Hydrol Eng. 13 (8), 735, 2008

9. MATULOVA Z., HLAVINEK P., DRTIL M. One-year operation of single household membrane bioreactor plant. Water Sci Technol. 61 (1), 217, 2010.

10. VERMA M., ET AL. Aerobic Biofiltration Processes Advances in Wastewater Treatment. Pract Period Hazard, Tox, and Radioact Waste Manage. 10 (4), 364, 2006.

11. SOVIK A.K., KLOVE B. Phosphorus retention processes in shell sand filter systems treating municipal wastewater. Ecol Eng. 25, 68, 2005.

12. VAN DER AKKER B., ET AL. Application of high rate nitrifying trickling filters to remove low concentrations of ammonia from reclaimed municipal wastewater. Water Sci Technol. 61 (10), 2425, 2010.

13. ROBERTSON W.D. Nitrate removal rates in woodchip media of varying age. Ecol Eng. 36, 1581, 2010.
14. ALONSO Á., CAMARG J. Ecological and toxicological effects of inorganic nitrogen pollution in aquatic ecosystems: A global assessment. Environ International. 32 (6), 831, 2006.

15. MOORMAN T.B., ET AL. Denitrification activity, wood loss and $\mathrm{N}_{2} \mathrm{O}$ emissions over nine years from a wood chip bioreactor. Ecol Eng. 36, 15674, 2010.

16. AIVASIDIS A., KAPAGIANNIDIS A.G., ZAFIRIADIS I. Biotechnological Methods for Nutrient Removal from Wastewater with Emphasis on the Denitrifying Phosphorus Removal Process. Reference Module in Earth Systems and Environmental Sciences, from Comprehensive Biotechnology (Second Edition). 6, 341, 2011.

17. LI G., ET AL. Denitrification with corncob as carbon source and biofilm carriers. Water Sci Techn. 65 (7), 1238, 2012.

18. ALI I., GUPTA V.K. Wastewater Treatment by Biological Methods. Environ Water. Advances in Treatment, Remediation and Recycling. 179, 2013.

19. Regulation on Wastewater Management (in Lithuanian language: Nuoteku tvarkymo reglamentas). D1-236. Vilnius, 2006 [In Lithuanian].

20. LAND 21-01. Environmental Rules of household water filtration equipment's for installation in natural conditions (in Lithuanian: Aplinkosauginès buitinių nuotekų filtravimo ịrenginių įrengimo gamtinèmis sąlygomis taisyklès). State News (in lithuanian language: Valstybès žinios). 2001-05-16; 41-1438:8, 2001 [In Lithuanian].

21. NASR F.A., MIKHAEIL B. Treatment of domestic wastewater using modified septic tank. Desalination Water Treat. 56, 2073, 2015.

22. MOUSSAVI G., KAZEMBEIGI F., FARZADKIA M. Performance of a pilot scale up-flow septic tank foro n-site decentralized treatment of residential wastewater. Process Saf Environ. 88, 47, 2010.

23. European Parliament - EP. Urban wastewater treatment. European Directive 1991/271/EEC of 1991.05.21. Brussels. 1991.

24. MAUNOIR S., PHILIP H., RAMBAUD A. Small wastewater treatment plants in mountain areas: combination of septic tank and biological filter. Water Sci Technol. 56 (10), 65, 2007.

25. DUCEY T.F., ET AL. Characterization of a microbial community capable of nitrification at cold temperature. Bioresource Technol. 101, 491, 2010.

26. ALMSTRAND R., LYDMARK P., LINDGREN P.E., SORENSSON F., HERMANSSON $M$. Dynamics of specific ammonia-oxidizing bacterial populations and nitrification in response to controlled shifts of ammonium concentrations in wastewater. Appl Microbiol Biotechnol. 97 (5), 2183, 2013.

27. SAJUNI N.R., AHMAD A.L., VADIVELU V.M. Effect of filter media characteristics, $\mathrm{pH}$ and temperature on the ammonia removal in the wastewater. J Appl Sci. 10 (12), 1146, 2010.

28. LYDMARK P., ALMSTRAND R., SAMUELSSON K., MATTSSON A., SORENSSON F., LINDGREN P.E., HERMANSSON M. Effects of environmental conditions on the nitrifying population dynamics in a pilot wastewater treatment plant. Environ Microbiol. 9 (9), 2220, 2007.

29. EIKELBOOM D.H. Process Control of Activated Sludge Plants by Microscopic Investigation. 156, 2000.

30. AL-JAMAL W., MAHMOUND N. Community onsite treatment of cold strong sewage in a UASB-septic tank. Bioresource Technol. 100, 1061, 2009. 
31. Phosphorus and Water. 2014. Available online: http://water.usgs.gov/edu/phosphorus.html. Sited 2 January 2016.

32. ABBAS H., SEIF H., MOURSI A. Effect of hydraulic retention time on the activated sludge system. Sixth International Water Technology Conference (IWTC), Alexandria, Egypt. 277, 2001.

33. SCHIPPER L.A., CAMERON S.G., WARNEKE S. Nitrate removal from three different effluents using large-scale denitrification beds. Ecol Eng. 36, 1552, 2010.
34. HARADA H., DONG N.T., MATSUI, S. A measure for provisional-and-urgent sanitary improvement in developing countries: septic-tank performance improvement. Water Sci Technol. 58 (6), 1305, 2008.

35. MASSOUD M.A., TARHINI A., NASR J.A. Decentralized approaches to wastewater treatment and management: Applicability in developing countries. J Environ Manage. 90, 652, 2009. 
